\title{
CURRENT STUDY OF PHYSICO-CHEMICAL PARAMETERS IN LABHANSARAD DAM IN WARORA TALUKA OF CHANDRAPUR DISTRICT, MAHARASHTRA STATE, INDIA.
}

\author{
S. S. Khiratkar ${ }^{1}$ S. K. Waware ${ }^{2}$ R. R. Kamdi $^{3}$ \\ ${ }^{1}$ S. P. College Chandrapur. \\ ${ }^{2}$ Gramgeeta Mahavidyalaya, Chimur. \\ ${ }^{3}$ Anand Niketan College Anandawan Warora
}

\begin{abstract}
:
The habitats of freshwater such as reservoirs, dam, lakes, ponds and tanks hold almighty assurance as dominantly source of drinking water and irrigation. The today's need of mankind is the lively ecological status of freshwater bodies. Parameters like Temperature, $\mathrm{pH}$, conductivity, TDS, Turbidity and Dissolved Oxygen were analyzed to find out the physico-chemical nature of the dam water in Labhansarad dam respectively. The above parameters were monthly noted during Feb.2018 to July.2018 and calculations showing monthly values in the table and graphs.
\end{abstract}

Keywords: Almighty, ecological, Labhasarad dam. Parameters. Mankind.

\section{INTRODUCTION :}

The fresh water resources distributions is unequal throughout the global and the fresh water facilitation is becoming boggle day by day in consideration of population augmentation and sundry human activities. In the absence of fresh water resources, groundwater is exploited to meet the demand exerted by various sectors. The variation in the quality of wetland water in response to local geologic syntax and anthropogenic factors vindicate the evaluation of the quality of groundwater for any purposes including that for human consumption (Annapoorna H., and Janardhanab M.R., 2015). The advantage of economic and environmental that are achieve from the water (Picini and Harper, 2016). The physico-chemical and biological status in limnological point of view with respect to elevation of area, fisheries, agriculture and regular domestic uses of water (Ingale, 2016). The increasing anthropogenic activities in the contiguous catchment caused increased inflow of unprocessed sewage and solid wastes to the lake. It also indicates that the oligotrophic water bodies are slowly changing as mesotrophic and in future may be change as eutrophic (Shiddamallayya and Pratima 2008) hence we all have to word of honor for responsibility consequently.

\section{MATERIAL AND METHOD:}

Labhansarad dam located in Warora Taluka of Chandrapur District, Maharashtra State, India. It is situated in the remote area from the localities. Town Kotha at West direction 1 kilometer, at the north $1.5 \mathrm{Km}$ Mahalgaon, town Sumthana $1.5 \mathrm{~km}$ towards the East- Sauth direction and town Lonar $1.5 \mathrm{~km}$ towards South direction from the location of Labhansarad dam. The study carried out for the Six month during February 2018 to July 2018 for analysis the some physico-chemical parameters such as, temperature, conductivity, total dissolved solid, turbidity, $\mathrm{pH}$, dissolved oxygen will be performed at the site using portable water analysis kit using methods prescribed by APHA (1985) and NEERI (1986).

\section{RESULTS AND DISCUSSION}

Temperature: Water temperature is the most important physico-chemical factor for the 
hydrobiological studies point of view. In the months of May, maximum atmospheric temperature and moderate pollutants in dam water is due to low quantity of water may be responsible for increasing in the values of temperature at Station -B. In the month of February minimum atmospheric temperature and high level of dam water might be responsible for minimum value of the water temperature at stations D, C, A, and E respectively. The similar line investigations reported by Sharma and Walia (2014).

Conductivity: It depend upon the ionic status of water. Ionic status of water determines the conductivity of water. The maximum value of conductivity recorded in the month of July might be due to inflow carries surface runoff from agricultural area of the dam at station- B, containing decaying organic matter, and may be due to the higher total dissolved solids. While minimum in the month of February may be due to expression of low ionic substance and decreased in total dissolved solid range responsible for decreasing the value conductivity at station - E. Same argument had also support to our findings recorded by Ajayan and Naik (2014) Ingale et al., (2015).

Total dissolved solid: Total dissolved solids are resolute as the residue remains left after evaporation of filtered sample. The maximum TDS observed in the month of July may be due to surface runoff, due to surface inflow to the dam at station $\mathrm{B}$, cloth washing, bathing activities and cattle activities (at station A, C and $D$ respectively) generate inorganic matter into the dam. Minimum TDS value noted in the month of February might be due to the lower temperature and high water level. Analogous findings recorded by Pawale and Lokhande (2012) and Choudhary et al., (2014).

Turbidity : Turbidity, the optical material goods given to the water by suspended solids, disturbs human observation visually. The maximum turbidity noted in the month of July at station B, might be due to the inflow gathering clay, slits and suspended particles into the dam water also decaying vegetation, high planktonic growth was responsible for the turbidity at station - B, A, C and $\mathrm{D}$. The minimum turbidity in the month of February at station E, may be due to settlement of silt, clay and suspended particles at station E. The values are corroborated with the study of Saxena (2012).

pH: The opinion that nearly neutral $\mathrm{pH}$ of water is synchronized by the carbon dioxide and bicarbonates. The hydrogen ion concentration of natural water is a vital factor which is associated with all life processes and also influences the immigration of an aquatic macro fauna in the water bodies (Hutchinson 1957). The maximum $\mathrm{pH}$ noted in the month of May and June, might be due to the increased carbonates and bicarbonate in dam water at station B. Minimum $\mathrm{pH}$ noted in the month of February and April, may be due to total dissolved solid, low turbidity and lower water temperature at station - E. Similar findings recorded by Bobdey et al., (2014) in Bhiwapur Lake, Dist. Nagpur (M.S) India.

Dissolved oxygen: Dissolved oxygen determines the distribution of aquatic organisms. The maximum dissolved oxygen recorded in the month of February, may be due to the circulation of cold water as well as higher solubility of oxygen at the temperature at station - E. The minimum DO noted in the month of May might be due to the lower water level demand for oxygen, higher temperature responsible to enhance microbial activities and decomposition can reduce D.O level at station B, C, A and D. The present findings amply supported by Shyam and Khatri (2015) and Ingale (2016). 


\section{CONCLUSION}

Finally it concluded that the physico chemical characteristics play an important role to maintain the quality of water and to sustain fish fauna in any stagnant inland water body. Present investigation therefore, stated that the causes of low fish production and high rate of fish mortality in these experimental ponds might be due to lack of proper management of water quality physico chemical parameters and irrigation purpose. Pollutants from different sources such as domestic wastes, surface runoff, washing of clothes, residues from traditional fish farming system etc. are entering into the ponds and creating the environment unsuitable for fish culture. Proper management of water quality parameters by controlling agricultural, urban and storm water run-off, maintaining septic system and applications of fertilizers would have probably the most effective measures to improve the fish production in these ponds. From this short-term survey on physico-chemical parameters, it could be concluded that there is an urgent need for additional research for betterment of water quality and sustainable production of fish in this region of Warora Taluka of Chandrapur District in Maharashtra State of India as well.

\section{ACKNOWLEDGEMENT}

The authors are grateful to the Dr. R. P. Ingole, Principal, S. P. College, Chandrapur, Dr.A .A.Dhamani, Principal, Gramgeeta Mahavidyalaya, Chimur and Dr.Mrunal Kale, Principal, Anand Niketan College, Warora for their cordial support and authorities of water quality and pond dynamics laboratory.

\section{REFERENCES :}

Ajayan K. V. and Naik Parameswara T. (2014): Physico-chemical characteristics of a fresh water lake Koppa, Bhadravathi Taluk, Shimoga District, Karnataka, India. Int. Res. J. Environment Sci. Vol. 3, (11): 5256.
APHA (1985) Standard methods for examination of water and waste water, 16th Ed. APHAAWWAWPCF. Washington DC.20036.

Annapoorna H., and Janardhanab M.R. (2015): Assessment of Groundwater Quality for Drinking Purpose in Rural Areas Surrounding a Defunct Copper Mine. Aquatic Procedia 4, ICWRCOE. doi: 10.1016/j.aqpro.2015.02.088.: 685 - 692.

Bobdey A. D., Ingale P. P. and Lonkar A. N . (2014): Evaluation of water quality in Bhiwapur Lake, Dist. Nagpur (M.S) India on the basis of some physico-chemical parameters. International Journal of Researches in Biosciences, Agriculturs and Technology. Special Issue.

Choudhary Jyoti, Singh S. N. and Singh Sunita (2014): Physico-chemical and biological parameters of the Three Rural Ponds of Sasaram of Bihar, Int $J$ Appl Sci Biotechnol. Vol. 2, (1): 206-210.

Ingale P. P., Bobdey A. D. and Lonkar A. N. (2015): Monthly variations in physicochemical characteristics of Bhiwapur Lake dist. Nagpur (M.S) India. Journal of Innovation in Science (JIIS) Vol.-II, (2).

Ingale P. P. (2016). A study of physico-chemical and biological status of Bhiwapur lake, Dist. Nagpur (M.S.), India. R.T.M. Nagpur University Nagpur.

Mogalekar H.S., Adnankhan Golandaj, Ansar C .P., Raman N.N. and Devkate Ajinkya (2015): Temporal Variation in the Hydrobiology of Vembanad Lake at PanangadKumbalam Mangrove Patches of Kochi, Kerala. Res. J. Animal, Veterinary and Fishery Sci., Vol. 3, (3): 1-7.

NEERI (1986): Manual on water and waste water analysis, National Environmental Engineering Research Institute Nagpur (M.S) India.

Pacini N., Harper D. (2016). Hydrobiological characteristics and water resources 
management in the Nile basin. Ecohydrol. Hydrobiol. $\mathrm{xxx} \mathrm{xxx}-\mathrm{xxx} 8$.

Pawale R. G. and Lokhande M. V. (2012): Studies on physico-chemical parameter of Dhanora reservoir in Nanded district, Maharastra, Water Research and Development. 2, (3 ): 76-78.

Saxena Meenakshi (2012): Water quality and trophic status of Raipur reservoir in Gwalior, Madhya Pradesh India. J N S R. Vol. 2, (8).

Sharma Vandana and Walia Yogesh Kumar (2014) Analysis of water quality using physicochemical parameters of Govind Sagar Lake H.P. (India). Asian J. of Adv. Basic Sci. 2, (3): 83-91.

Shiddamallayya M. and Pratima M. (2008): Impact of domestic sewage on fresh water body. J E B. Vol. 29, (3): 303-308.

Shyam Sunder and Khatri A. K. (2015): Physico-chemical properties of water of Ottu Reservoir in District Sirsa, Haryana, India. R. J. R. S. Vol. 4: 190-196.

Table no.1: Table showing Monthly Variation of some physico-chemical parameters in Labhansarad Dam during Feb.2018-Apr.2018.

\begin{tabular}{|c|c|c|c|c|c|c|c|c|c|c|c|c|c|c|c|c|}
\hline \multirow{3}{*}{$\begin{array}{l}\text { Sr. } \\
\text { no }\end{array}$} & \multirow{3}{*}{$\begin{array}{l}\text { Months } \rightarrow \\
\text { Parameters } \downarrow\end{array}$} & \multicolumn{5}{|c|}{ Feb. } & & \multicolumn{5}{|l|}{$\begin{array}{l}\mathbf{A p} \\
\mathbf{r}\end{array}$} \\
\hline & & \multicolumn{5}{|c|}{$\begin{array}{l}\text { Stati } \\
\text { on } \downarrow\end{array}$} & \multicolumn{5}{|l|}{$\begin{array}{l}\text { Stat } \\
\text { ion } \downarrow\end{array}$} & \multicolumn{5}{|l|}{$\begin{array}{l}\text { Sta } \\
\text { tio } \\
\mathbf{n} \downarrow\end{array}$} \\
\hline & & $\mathbf{A}$ & B & $\mathbf{C}$ & D & $\mathbf{E}$ & $\mathbf{A}$ & B & $\mathbf{C}$ & D & $\mathbf{E}$ & $\mathbf{A}$ & B & $\mathbf{C}$ & D & $\mathbf{E}$ \\
\hline $\mathbf{1}$ & Temp. & 20 & 20.5 & $\begin{array}{l}20 . \\
1\end{array}$ & 20.2 & 20.4 & 27.4 & 28 & 27.2 & 27.1 & 27.5 & $\begin{array}{l}26 . \\
8\end{array}$ & $\begin{array}{l}27 . \\
5\end{array}$ & $\begin{array}{l}26 . \\
7\end{array}$ & $\begin{array}{l}26 . \\
4\end{array}$ & $\begin{array}{l}26 . \\
8\end{array}$ \\
\hline 2 & Cond. & 200 & 247 & 221 & 213 & 145 & 230 & 269 & 245 & 220 & 148 & $\begin{array}{l}22 \\
2\end{array}$ & $\begin{array}{l}26 \\
5\end{array}$ & $\begin{array}{l}24 \\
0\end{array}$ & $\begin{array}{l}21 \\
6\end{array}$ & $\begin{array}{l}14 \\
3\end{array}$ \\
\hline 3 & TDS & 146 & 190 & 169 & 157 & 96 & 175 & 203 & 191 & 171 & 101 & $\begin{array}{l}16 \\
8\end{array}$ & $\begin{array}{l}19 \\
7\end{array}$ & $\begin{array}{l}17 \\
7 \\
\end{array}$ & $\begin{array}{l}16 \\
5\end{array}$ & 93 \\
\hline 4 & Turbidity & 2 & 4 & 3 & 2 & 1 & 2 & 5 & 4 & 3 & 2 & 2 & 5 & 4 & 3 & 1 \\
\hline 5 & pH & 7.3 & 7.4 & 7.3 & 7.2 & 7.1 & 7.3 & 7.4 & 7.4 & 7.3 & 7.2 & 7.2 & 7.4 & 7.4 & 7.2 & 7.1 \\
\hline 6 & DO & 7.2 & 6.9 & 7.2 & 7.6 & 8.2 & 7 & 6.5 & 6.7 & 6.9 & 7.5 & 7.1 & 6.7 & 6.9 & 7 & 7.6 \\
\hline
\end{tabular}




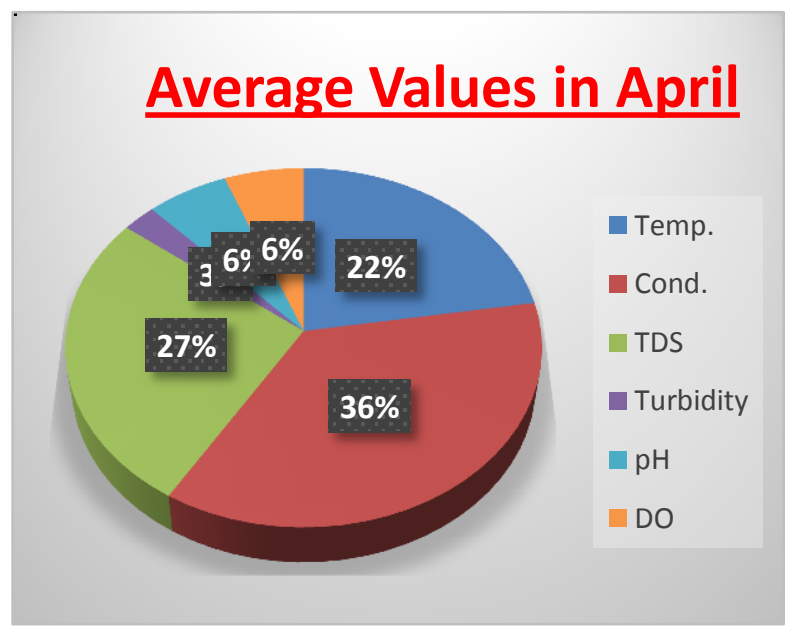

\section{Average values in}

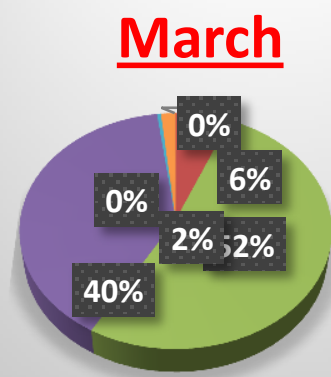

- March

- Temp

Cond.

TDS

Turbidity

\section{Average Values in June}

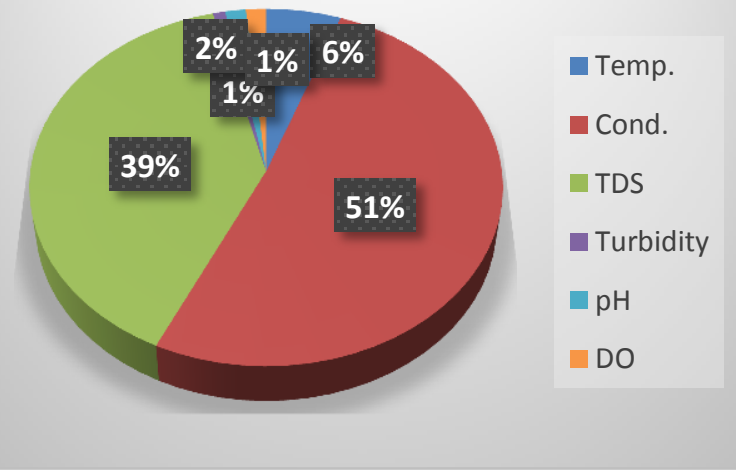

\section{Average Values in Feb.}

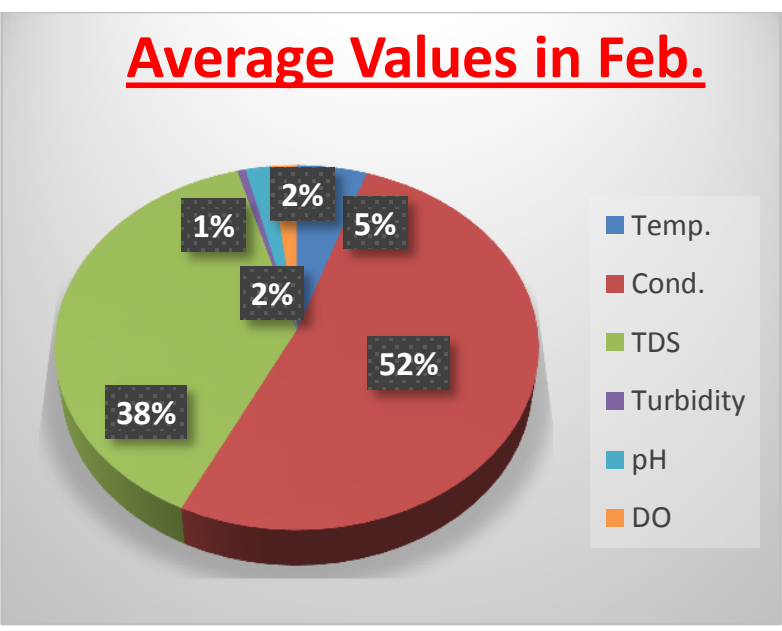

\section{Average Values in May}

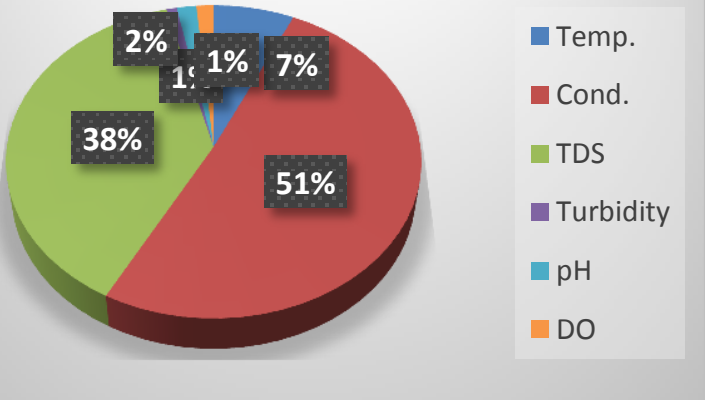

\section{Average Values in July}

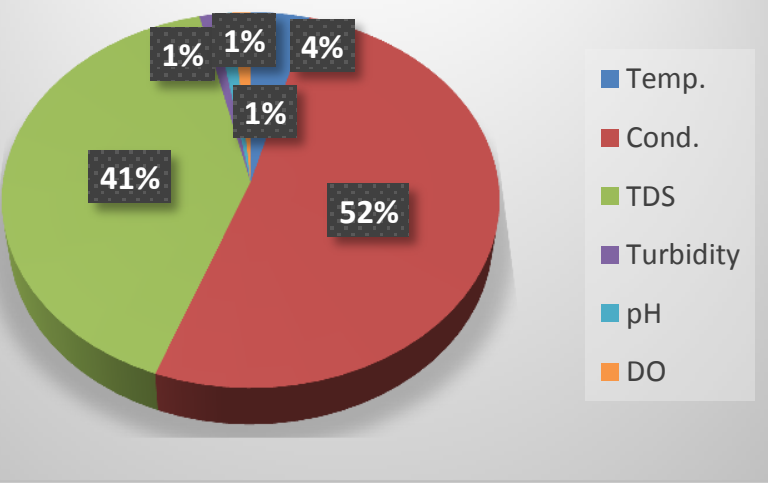

Table no.1: Table showing Monthly Variation of some physico-chemical parameters in Labhansarad Dam during May.2018-July.2018.

\begin{tabular}{|c|c|c|c|c|c|c|c|c|c|c|c|c|c|c|c|c|}
\hline \multirow{3}{*}{$\begin{array}{l}\text { Sr. } \\
\text { no }\end{array}$} & \multirow{3}{*}{$\begin{array}{c}\text { Months } \rightarrow \\
\text { Parameters } \downarrow\end{array}$} & \multicolumn{5}{|c|}{ May } & \multicolumn{5}{|c|}{ June } & \multicolumn{5}{|c|}{ July } \\
\hline & & \multicolumn{5}{|c|}{ Station $\downarrow$} & \multicolumn{5}{|c|}{ Station $\downarrow$} & \multicolumn{5}{|c|}{ Station $\downarrow$} \\
\hline & & A & B & $\mathbf{C}$ & D & $\mathbf{E}$ & $\mathbf{A}$ & B & $\mathbf{C}$ & D & $\mathbf{E}$ & $\mathbf{A}$ & B & $\mathbf{C}$ & D & $\mathbf{E}$ \\
\hline 1 & Temp. & 30.6 & 31.6 & 31 & 30.9 & 31.1 & 26.4 & 27.1 & 26.8 & 26.3 & 26.9 & 23.2 & 23.9 & 23.4 & 23.2 & 23.5 \\
\hline
\end{tabular}




\begin{tabular}{|l|l|c|c|c|c|c|c|c|c|c|c|c|c|c|c|c|}
\hline $\mathbf{2}$ & Cond. & 241 & 278 & 257 & 224 & 150 & 259 & 291 & 268 & 253 & 162 & 304 & 344 & 319 & 295 & 189 \\
\hline $\mathbf{3}$ & TDS & 187 & 211 & 182 & 173 & 105 & 196 & 239 & 206 & 179 & 114 & 255 & 275 & 249 & 234 & 132 \\
\hline $\mathbf{4}$ & Turbidity & 3 & 6 & 5 & 3 & 3 & 4 & 6 & 5 & 4 & 3 & 5 & 8 & 7 & 5 & 4 \\
\hline $\mathbf{5}$ & pH & 7.5 & 7.7 & 7.6 & 7.5 & 7.3 & 7.3 & 7.6 & 7.5 & 7.4 & 7.2 & 7.3 & 7.5 & 7.4 & 7.3 & 7.2 \\
\hline $\mathbf{6}$ & DO & 6.8 & 6.1 & 6.3 & 6.8 & 7.1 & 7.2 & 6.9 & 7 & 7.3 & 7.6 & 7.3 & 7.1 & 7.2 & 7.4 & 7.7 \\
\hline
\end{tabular}

